porphyry which traverse the district, and are of slightly later date than the granite. Fifty-seven pages are devoted to economic geology and mining, much information being given about the mineral lodes and the mines, some of which are now being re-opened.

Brief accounts are given of the Pliocene deposits of St. Erth and of the later Pleistocene accumulations.

The photographic views are clear and well reproduced, as may be seen from the example here given. The map is well printed on good thick paper, and the only fault we have to find with the colouring is that the tints indicating Pliocene and Valley Gravel are barely distinguishable from one another.

(2) The second memoir deals with an area which includes parts of Berkshire, Wiltshire, and Hampshire, the larger portion being in Berkshire and traversed by the valley of found in two small outliers, which are due to shallow syncinal flexures.

By aid of this zonal work $\mathrm{Mr}$. White is able to show the exact nature and extent of the unconformity between the Chalk and the Eocene. This proves to be a gradual overstep, the Eocene passing transgressively on to older and older beds in a northerly direction. Hence it would seem that, prior to the Eocene sedimentation, the whole area hat a continuous slope from north to south, and that the Kingsclere-Pewsey anticline is entirely of post-Eocene date. Chapters are devoted to the Reading beds, the London Clay, the Lower Bagshot beds, the Clay-with-Flints, the Plateau Gravel, the valley gravels, alluvium, and economics. There are also appendices on the Mollusca of the ailuvium of the Kennet by Messrs. A. S. Kennard and B. B. Woodward, and on the insoluble matter in

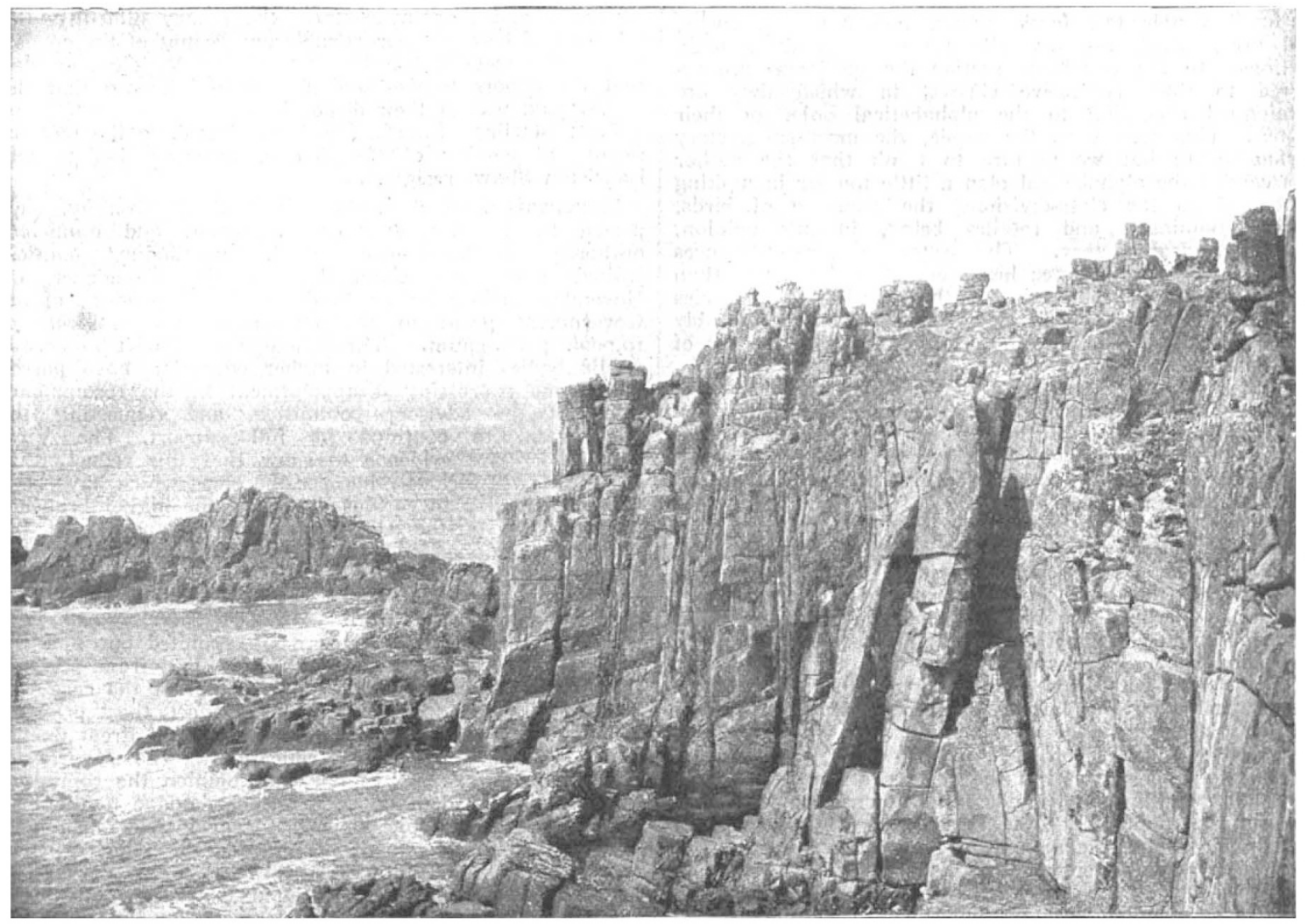

View of the south side of the Land's End. From "The Geology of the Land's End District."

the Kennet. Nothing older than the Selbornian (Upper Greensand) reaches the surface, and the greater part is occupied by Chalk, Eocene beds, and Clay-with-flints. The colouring of the map is clear, and the paper on which it is printed is thicker than that of sheets issued in previous years.

It is some time since this area was surveyed, and in the meantime Mr. Osborne White has made a detailed studv of the Chalk and its zones in Berkshire, as well as of the superficial deposits of this and neighbouring districts, so that the preparation of the memoir could not have been put into better hands.

Of the Cretaceous rocks described, the chief interest centres in the Upper Chalk, which is dealt with zone by zone; two of these, the zone of Marsupites testudinarius and that of Actinocamax quadratus, have only been proved to exist in Berkshire within the last three years. The former has a continuous outcrop from the western border as far east as Newbury, and this outcrop is indicated on a sketch-map in the memoir; but the higher zone is only samples of Upper Chalk by Dr, W. Pollard and Mr. H. H. Thomas. Finally, the memoir is furnished with a bibliography and a good index.

\section{RECENT PUBLICATIONS OF THE U.S.} MUSEUM. ${ }^{1}$

THE subjoined list (which is exclusive of a large number of minor publications) affords a striking example of the energy with which scientific research is being pushed in America, a noteworthy fact being that, 1 ( $x$. "The Birds of North and Middle America". Part.iv. By R Ridgway. Bull. U.S. Nat. Museura, No. 5o. Pp. xxii +973-

(2) "Catalogue of the Type and Figured Specimens of Fossils, Minerals, Rocks, and Ores in the Department of Geology, U.S. Mus." Part it. By J.P. Merrill. Op. cit., No. 53 . Pp. v+37o.

(3) "The Families and Genena of Bats." By G. S. Miller. $Q p, c i$ No. 57. Pp. xvii +282 .

(4) "Herpetology of Japan and Adjacent Territory." By L. Stejneger Op. cit., No. 58. Pp. $\mathrm{xx} \div 577$.

(5) "Report on the Diatoms of the Albatross Voyages in the Pacific Ocean, r888-1904." By Albert Mann. Conגr. U.S. Nat. Herbarium, vol. x.r part v. Pp. v+221-424.

NO. I987, VOL. 77] 
out of the five memoirs, only two are devoted solely to American biological subjects. Since all five are by wellknown experts, the following brief remarks may in the main take the form of commendation rather than of criticism.

As regards No. I, Mr. Ridgway is to be congratulated on having got through rather more than half his heavy task, the present part bringing him nearly to the conclusion of the perching birds, of which no less than 1675 species and races are recorded in the first four parts. As in the previous volumes, generic terms are employed in the modern restricted sense, and the "keys" to the various family and generic groups are all that can be desired in the way of lucidity and comprehensiveness.

The catalogue standing as No. 2 in our list is a work exclusively for the benefit of specialists, to whom it will no doubt prove invaluable. The invertebrates having been completed in the first part, the present issue is devoted to fossil vertebrates, fossil plants, and minerals, rocks, and ores, which are severally arranged in three main sections. In the vertebrate section the specimens are referred to their respective classes, in which they are catalogued according to the alphabetical order of their names. This seems, on the whole, the most satisfactory arrangement; but we venture to think that the author has carried the alphabetical plan a little too far in making it extend to the class-divisions, the sequence of birds, fishes, mammals, and reptiles being, in our opinion, decidedly unsatisfactory. The system of cross-references in cases where a specimen has been referred to more than one genus is well planned, but the addition of a species index to each section or class would have considerably added to the value of the catalogue as a work of reference.

With No. 3 we come to a work of prime importance, which cannot fail to be of the highest value to systematists. No complete revision of the families and genera of bats has, we believe, been published since the issue of Dobson's invaluable catalogue, and as great progress in our knowledge of the group has been made since that date, such a revision was urgently wanted. For this task few zoologists are better equipped than Mr. Miller, who for some years past has devoted much attention to the order, and has studied the chief collection on both sides of the Atlantic. Perhaps the most important divergences from the Dobsonian classification are the wide sundering of the Emballonuridx and Vespertilionidx, and the transference of the mastiff-bats from the former group to a separate family following the latter; the second change being a further development of one inaugurated by Winge and endorsed by Max Weber.

Dr. Stejneger's work on the reptiles of Japan, the Liu Kiu and neighbouring islands, and a considerable proportion of the mainland of the Far East, will take rank as a valuable systematic monograph, in which special attention is devoted to geographical distribution.

In his memoir on the Pacific diatoms collected bv the Albatross, standing last on our list, the author directs attention to the importance of collecting these organisms on account of their value in determining difficult questions connected with the extent and volume of ocean currents. and the origin of the materials deposited on the bed of the sea. Now that this has been pointed out, there is little doubt that the authorities will see their way to the collection of diatoms in a much more careful and systematic manner than has hitherto been attemnted in America.

R. L.

\section{UNIVERSITY AND EDUCATIONAL INTELLIGENCE.}

CAMbridge.-The board of anthropological studies has put forward a proposal to establish a diploma in anthropology. The board believes that the interests of anthropology will be best served by the encouragement of research, and that the proposed diploma in anthropology should be granted for an original dissertation, and not by examination.

On the recommendation of the general board of studies the readership in animal morphology is to be transferred to the more general subject of zoology. It is proposed that the board be authorised to appoint a reader in zoology with the annual stipend of rool., to be paid from the common university fund. The board also proposes that a demonstrator in petrology be appointed.

Mr. W. Welsh has been appointed chairman of the examiners for part i. of the mathematical tripos, 1908 (new regulations).

Prof. Ridgeway, the Disney professor, gives notice that he will maintain the thesis " that Sergi's theory of "the Mediterranean race' is untenable," on Wednesday, December 4 , at 5 p.m., in the archæological lecture-room.

London.-At the meeting of the Senate on November 20 a report was received from the committee specially appointed to advise the Senate on the question of the establishment of the proposed Institute of Medical Sciences at South Kensington. The committee found that the financial support offered for the original scheme was inadequate, and that, apart from the money difficulty, the scheme had become impracticable on account of the opposition of the medical faculty. The Senate therefore decided that the donors to the fund should be informed that the money paid was at their disposal.

Prof. Starling, F.R.S., has been elected by the medical faculty a member of the Senate, in succession to Dr. Lauriston Shaw, resigned.

Manchester.-A deputation from the University, supported by the members of Parliament and municipal authorities of Lancashire and the surrounding counties, waited upon the Chancellor of the Exchequer on November 20 in reference to the proposed reduction of the Government grant to the University from 12,0ool. to 10,oool. per annum. Throughout this district numerous public bodies interested in higher education have passed resolutions expressing disappointment at the recommendation of the advisory committee, and requesting the Government to continue its full support. The ViceChancellor gave evidence to show that this reduction in the grant will seriously hamper the steps which have been taken to develop in various directions the higher branches of the work of the University. The Chancellor of the Exchequer emphasised the determination of the Government not to reduce the total grant of 10o, oool. devoted to higher education, but, whilst admitting that there was no suggestion that the work of the University had been slackened in any of its departments, pointed out that the advisory committee was unbiased and free from pressure from any quarter. Further consideration of the case was promised. Quite apart from its local effect, the "principle of a maximum" is regarded here as one of great danger to the advance of higher education. The Manchester Guardian remarks:--"In our own opinion the committe has not only incidentally done serious damage to the University, but it has done violence to a principle much more important than the one it has introduced. That principle is, that while there are many valid reasons why the amount spent by the State on educational institutions should be increased, there is only one valid reason for its ever being reduced-their inefficiency. It is right to penalise a college or a school because it does not come up to standard, but it is contrary to justice and to public policy to penalise one of which nothing but praise is uttered."

OXFORD.-A grant of $300 l$. having been made from the University chest to the professor of pathology for the provision of a lecturer and a demonstrator in his department, the professor has nominated Dr. E. W. Ainley Walker as lecturer in pathology.

SHefFIELd.-Mr. Haldane visited the University on November 20 , and inspected various departments and addressed a large gathering of the students, staff, and others, presided over by Sir Charles Eliot, the ViceChancellor. Mr. Haldane spoke of the developments of recent times which have brought universities into contact with industrial life. The closest connection of science and industry may be made to the lasting advantage of both, and without damage to either. It is becoming truer every day that no man can hope to control a great university who has not at his disposal resources which science alone can give. The laboratory and the professor have inspired No. 1987 , vOL. 77] 